\title{
Liver Leiomyosarcoma
}

National Cancer Institute

\section{Source}

National Cancer Institute. Liver Leiomyosarcoma. NCI Thesaurus. Code C5756.

An aggressive malignant smooth muscle neoplasm, arising from the liver. It is characterized by a proliferation of neoplastic spindle cells. 